\title{
HONG KONG LOGISTICS SKYSCRAPERS
}

\author{
Йордан Христов, $\partial-p$ арх. \\ УАСГ, АФ, кат. „Промишлени и аграрни сгради“ гр. София, България
}

DOI: https://doi.org/10.31435/rsglobal_ws/12072018/6009

\begin{abstract}
ARTICLE INFO
Received: 03 May 2018

Accepted: 19 June 2018

Published: 12 July 2018

\section{KEYWORDS}

plot ratio;

sustainable architecture; urban structure compactness; logistics skyscrapers

ABSTRACT

The publication reveals some architectural features of contemporary logistics buildings in Hong Kong with 15 and more floors, called in the article "logistics skyscrapers". These vertically developed spatial structures make it possible to preserve the urban structure compactness. At the same time they support the development of logistic business in the conditions of acute insufficiency of land for construction and a constantly growing need for logistics areas within the city boundaries, caused largely by the explosive development of the e-commerce branch. Evolution of the type is being analysed in the context of global economic interdependence and connectivity. Types of logistics skyscrapers are classified on the basis of arrangements, which are carried out through the vertical loading links.
\end{abstract}

Citation: Йордан Христов. (2018) Hong Kong Logistics Skyscrapers. World Science. 7(35), Vol.2. doi: 10.31435/rsglobal_ws/12072018/6009

Copyright: (C) 2018 Йордан Христов. This is an open-access article distributed under the terms of the Creative Commons Attribution License (CC BY). The use, distribution or reproduction in other forums is permitted, provided the original author(s) or licensor are credited and that the original publication in this journal is cited, in accordance with accepted academic practice. No use, distribution or reproduction is permitted which does not comply with these terms.

Логистичният небостьргач е специфичен архитектурен тип, характерен само за Хонконг. Той не се среща никъде дори в Азиатско - Тихоокеанския регион (Токио, Осака, Сингапур), за когото многоетажните логистични сгради с пет и повече нива за складиране и височини до 50 м. са обичайно пространствено решение [1].

Основните фактори за неговата поява са финансово-икономически:

- много висока цена на земята - 2,5 пьти по-висока отколкото в Сингапур и около 3,5 пьти по-висока в сравнение с Токио [1]

- експлозивното развитие на е-търговията през второто десетилетие на 21век и необходимостта от скъсяване на времето за реакция на потребителското търсене

- необходимост от нови логистични площи, свързана с нарастващите обеми на стоките и товарите в глобалната търговия и функциите на световен логистичен възел и на регионален разпределителен център, които изпълнява Хонконг. 26\% от годишния обществен продукт се генерират в отрасъла „Тьрговия и Логистика““ [2]

Предпоставките, които правят възможно и осъществимо изграждането на високи логистични сгради в „особения административен район“ на КНР са обективни и субективни.

В началото ще бъдат анализирани градоустройствените (субективни) фактори (регулации) за появата на „логистичния небостьргач“ в урбанизираните територии на Хонконг с общо-индустриално предназначение.

Определящо условие за интензивното използване на терените е Plot Ratio (PR), което е еквивалент на К интензивност и изразява отношението между разгънатата застроена площ и площта на имота. За съществуващите индустриални територии с общо предназначение - GIU (за лека индустрия, складиране, спомагателни офиси) в чертите на Хонконг, показателят варира между 5 и 12, като средният за територията не може да надхвърли 9,5. Новите бизнес територии в границите на метрополията са със средно $\mathrm{PR}-8$, като интензивността в различните имоти може да се колебае в по-широки граници 2,5 - 12 [3]. 
Схематичните строителни петна във „фигура 1“ предполагат максимална височина от 1819 етажа при Кинт = 12. При по-големи отстояния от външните и вътрешните регулационни линии и при застрояване на подиума с по-малка от 100\%-овата плътност, етажността може да достигне 20-25 нива, а височината - 130 - 150 м.

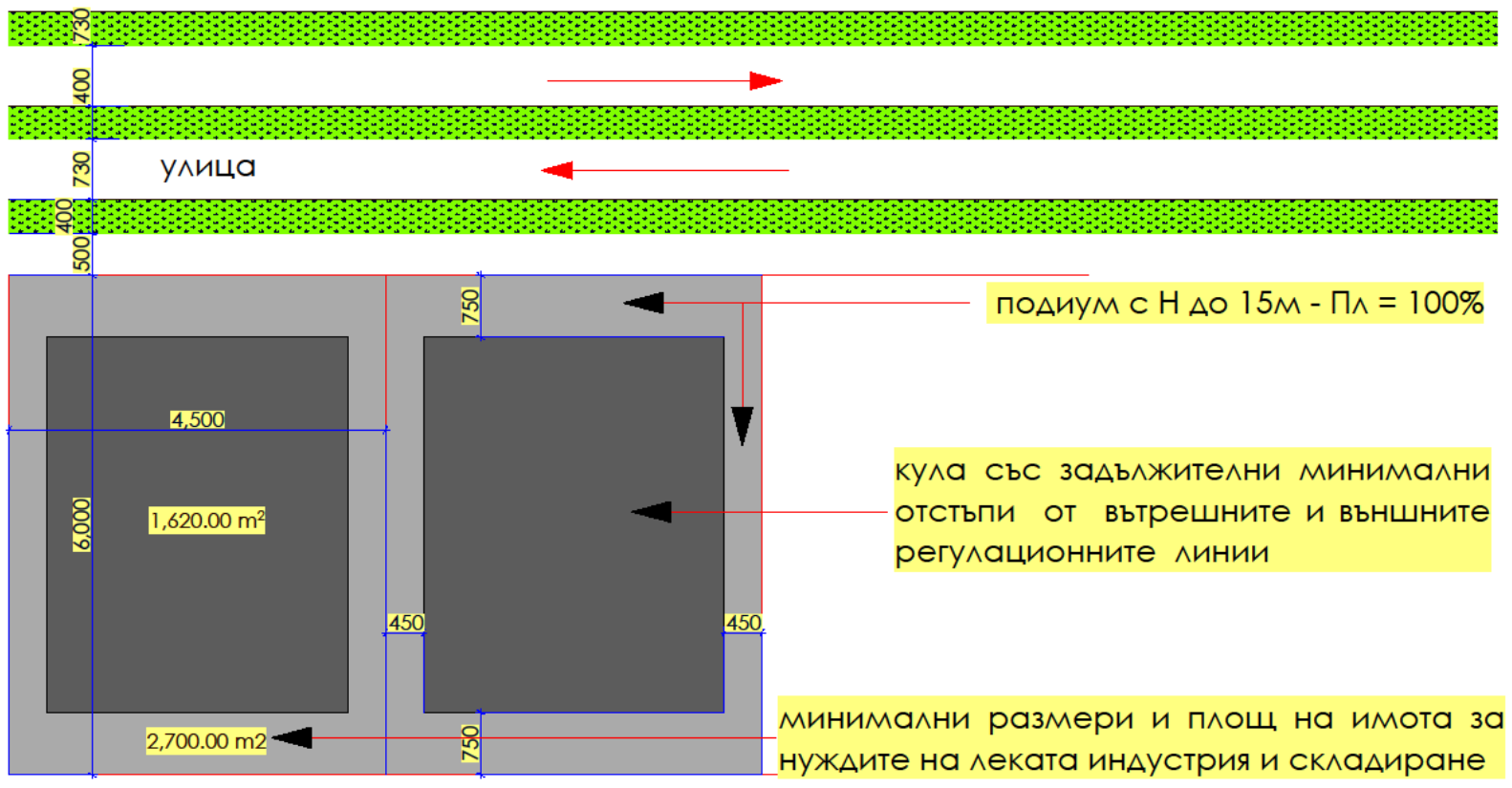

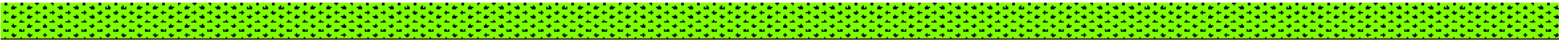

улица

Рис. 1 - Принциино застрояване на терени отредени за общуо-индустриално предназначение и организаџия на транспортните артерии според правилата за устройствено планиране в Хонконг

Много високите пльтности и интензивности, прилагани в устройственото планиране на Хонконг са адекватно субективно отражение на обективно лимитираните ресурси на терени за нуждите на строителство и са мощен фактор за повишаване на етажността сградите като цяло, в това число и на обектите, свързани с логистиката.

Друг субективен фактор, който предпоставя реализацията на сгради за складиране с височини от $120-150 \mathrm{M}$ е наличието на строителна традиция и широкото практическо приложение на различни технологии за дълбоко фундиране за жилищни и обществени сгради с височини 300-400м [4].

Обективната предпоставка за реализирането на пространствени структури на градската логистика с 20-25 етажа е ниският сеизмичен риск. Степента на сеизмичен риск се определя от близостта до контактната зона на 2 или повече тектонични плочи. Хонконг е разположен върху Евразийската плоча на повече от 500км от границата на Тихоокеанската, която преминава през Япония, Тайван и Филипините [5].

В условията на действащи обективни и субективни предпоставки във високоорганизираната урбанизирана структура на Хонконг се реализират три основни типа „логистични небостьргачи“.

\section{Типове високи логистични сгради}

В отговор на потребностите на логистичните фирми и в пряка зависимост от даденостите на конкретния парцел като размери и геометрия, плътност и интензивност на застрояването, както и отсъствието или наличието на ограничения във височината на застрояване, се реализират няколко подтипа на „логистичния небостъргач“ по белега - вертикален товарен транспорт. За илюстриране на многообразието и принципите на структуриране на различните типове високи сгради за градска логистика ще бъдат анализирани примери от практиката на транснационалната компания за недвижимости в областта на логистиката и бизнеса „GOODMAN““6]. 


\section{- с групи товарни асансьори -}

Характерно за този тип високи логистични сгради е, че товаро-разтоварните дейности се осъществяват в първите 2 приземни нива т. е. в „подиума“, Товарните асансьори са за общо ползване и с товароподемности 2.0 - 4.0т. Разполагат се обикновено в групи по 3 и повече асансьора, централно на обслужваната площ или по контура на сградата. При периферното разполагане товарните комуникации се комбинират с евакуационните стълбища и необходимите санитарни възли. Конструктивната система е скелетна с полета около 8,00/9,00м при KWAI CHUNG LOGISTISTICS CENTRE, около 10,50/12,00м при TEXACO CENTRE и около 12,00/16,50 при TZUEN WAN CENTRE. Светлата етажна височина е малка за този тип сгради - 3,00 - 4,20м, което предполага по-малки полезни товари - $750-1250 \kappa г / \mathrm{M}^{2}$ и позволява по-големи от обичайните подпорни разстояния.

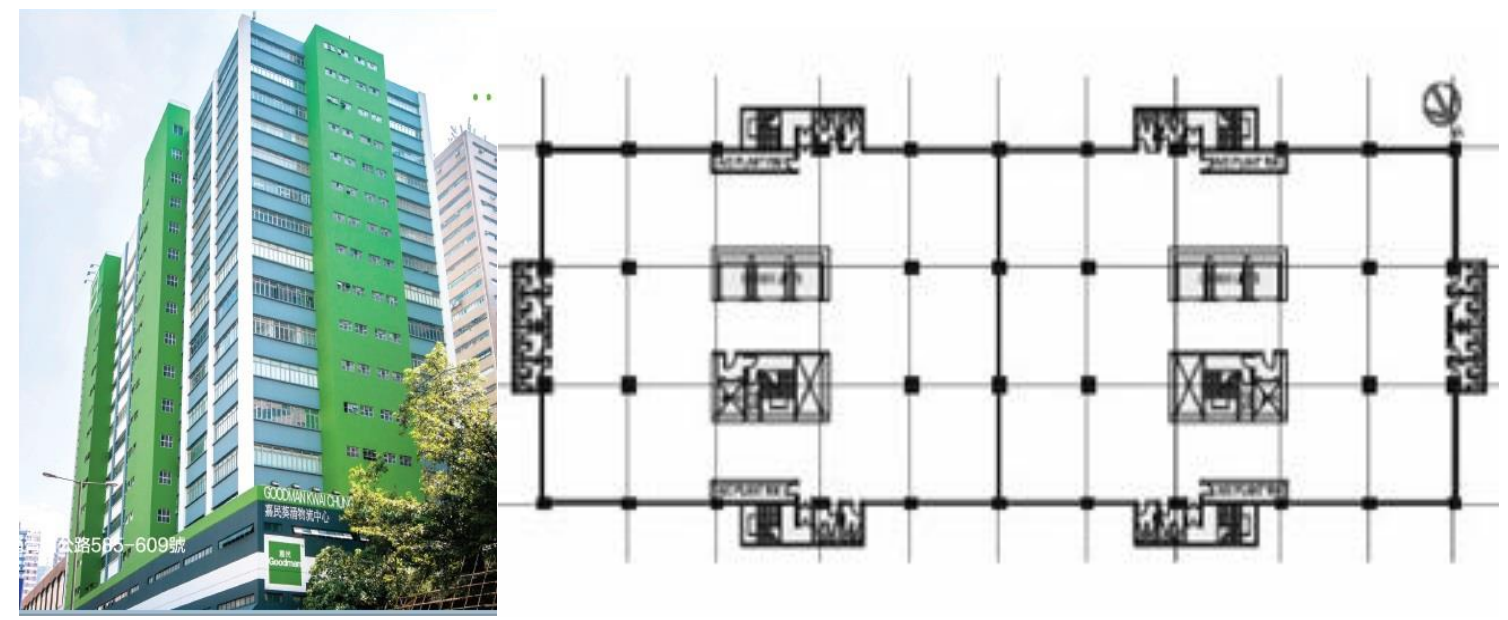

Puc. 2.- GOODMAN KWAI CHUNG LOGISTISTICS CENTRE в Хонконг - изглед и разпределение на типов етаж, обслужван от 6 товарни асансьора, разположени в ядрото на етажа, с товароподемност 2.0m. Светлата височина е 3,30-3,70 м. Полезният товар на междуетажната конструкция е $750 \kappa 2 / \mathrm{m}^{2}-1250 \kappa 2 / \mathrm{s}^{2}$
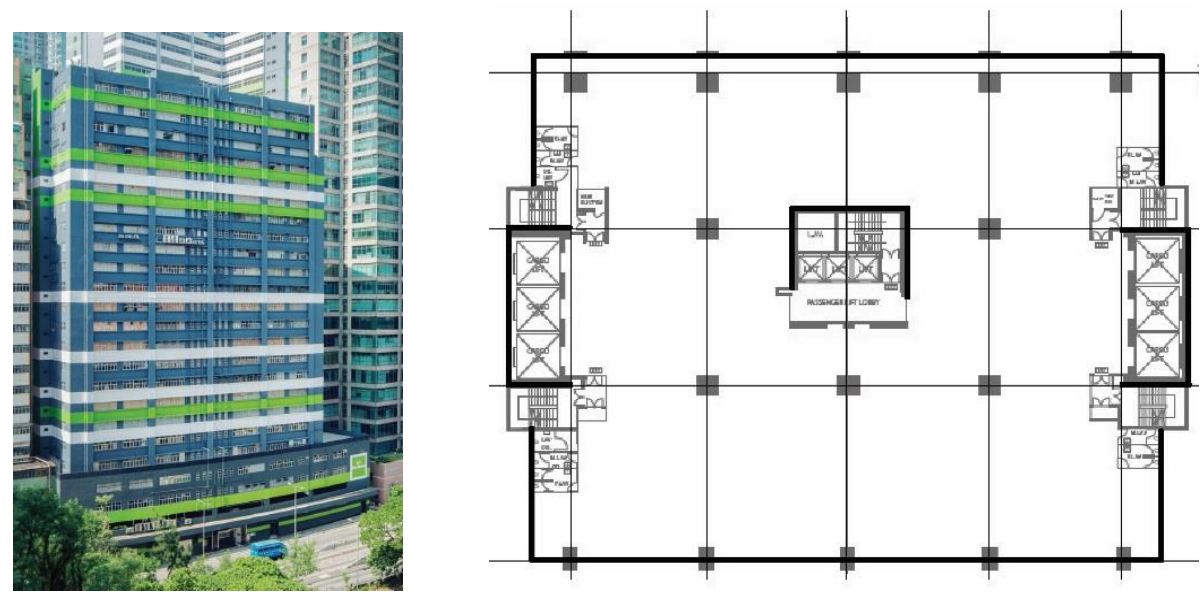

PUc. 3. - GOODMAN TEXACO CENTRE в Хонконг - изглед и разпределение на типов етаж, обслужван от 6 товарни асансьора с товароподемност 2.5m. Светлата етажна височина е

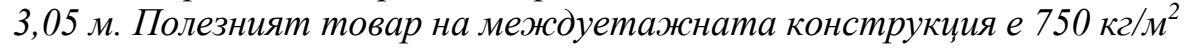

\section{- с товарни асансьори и контейнерни кранове -}

Могат да се смятат за разновидност на предишния тип с по-висока производителност, която се постига за сметка на окрупнените обеми товари, които се доставят и експедират от различните нива.Товарните комуникации обикновено се разполагат периферно от страната на контейнерните шахти при дълбочина на застрояването около 40м. По този начин в подиума се осигурява достъп на тежкотоварни автомобили с дължина 13,50 - 16,50м. За нормалната експлоатация на контейнерни кранове и поетажната обработка на 40 футовите контейнери е 
необходима ориентировъчна площ от $170-180 \mathrm{M}^{2}$ за шахта и контейнерно предверие за едно съоръжение. Конструкцията е скелетна с полета около 12,00/15,00м при GOODMAN DYNAMIC CENTRE. Светлата етажна височина е сравнително малка - 4,50м и полезният товар е $1250 \mathrm{kr} / \mathrm{m}^{2}$, което позволява преодоляването на по-големите подпорни разстояния.
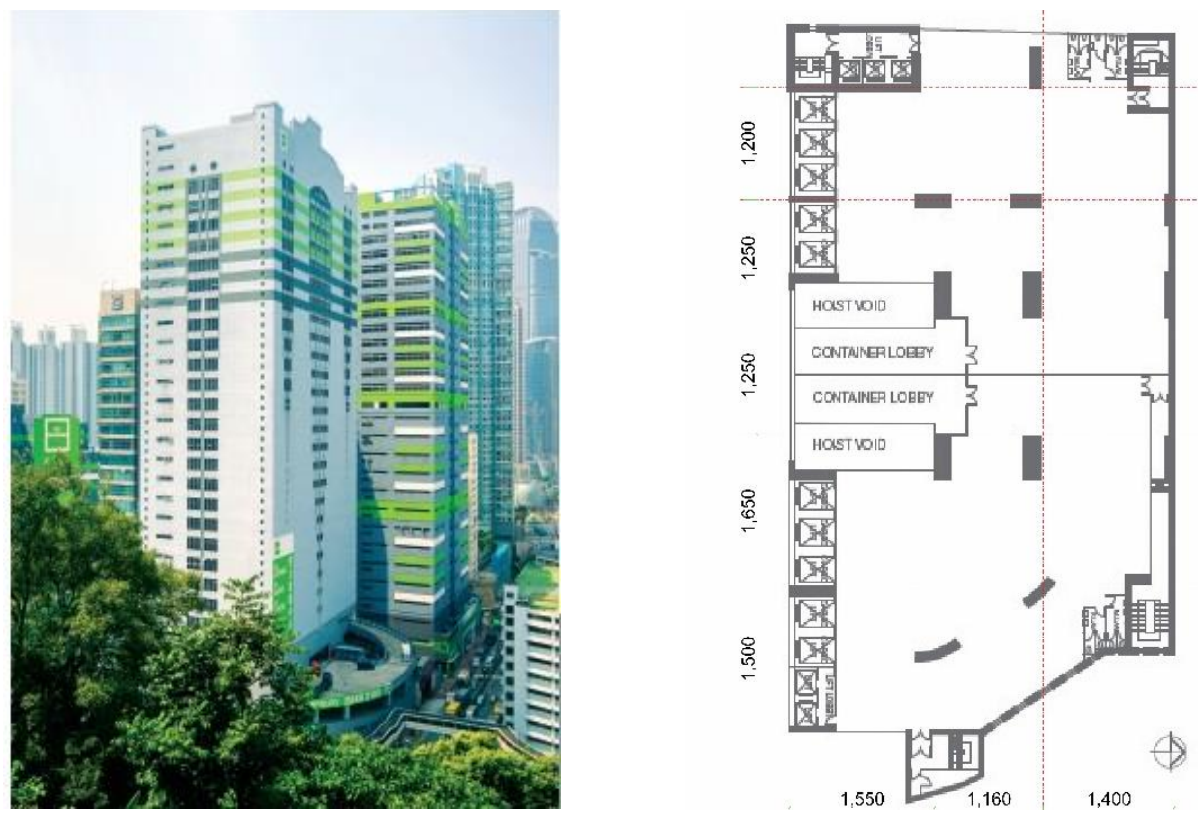

Puc. 4. - GOODMAN DYNAMIC в Хонконг - изглед и разпределение на типов етаж, обслужван от 10 товарни асансьора с товароподемност $3.0 \mathrm{~m}$ и 2 контейнерни крана. Светлата височина е 4.80 м. Полезният товар на междуетажната конструкиия е $1250 \mathrm{\kappa} 2 / \mathrm{m}^{2}$

- с двупосочни криволинейни рампи (4 ленти) и товарни асансьори-

Характерно за третия тип високи логистични сгради, използван в Хонконг, е че повисоката производителност се постига за сметка на по-неблагоприятното отношение на полезната към обслужващата площ в рамките на разгънатата застроена площ. При GOODMAN INTERLINK в етажите с достъп на тежък товарен транспорт /1- 15/ обслужващите площи - за транспортни и товаро-разтоварни дейности - заемат около 45\%. По-добър е балансьт в GOODMAN GLOBAL GATEWAY, където комуникационните площи за автомобилен транспорт заемат около $1 / 3$ от площта на етажа.

Друга особеност на този тип сгради е различната етажна височина в зависимост от вида на товарния транспорт. Нивата, които се обслужват директно от автомобилен транспорт обикновено са със светли височини около $-6,00-6,40 \mathrm{M}$, а тези с товарни асансьори $-4,80-5,40 \mathrm{M}$. Полезните товари са различни за различните етажи - 1250 кг $/ \mathrm{M}^{2}$ за по ниските и $1500-1800 \mathrm{\kappa} / \mathrm{m}^{2}$ за по-високите.

Товарните асансьори са за общо ползване и с товароподемности 3.0 - 5.0т. Блокирани обикновено в групи по 2 по контура на сградата, подобно на втория тип, те освобождават централната зона на подиума за маневриране и обработка на контейнеровози и други по-леки товарни автомобили, обслужващи 6-12 етажа със складова площ 40-45,000м ${ }^{2}$ /в случая с INTERLINK u GLOBAL GATEWAY/.

Криволинейните рампи са с ефективна широчина на пьтното платно от 15,00м. То е съставено от четири ленти за движение.

Конструктивните полета са по-големи от използваните в пьрвите два типа високи складови сгради поради необходимостта от осигуряване на свободни пространства за маневриране на тежкотоварни автомобили във вътрешността на сградата - около 13,80/19,50м в INTERLINK и 12,50/16,00м в GLOBAL GATEWAY. 

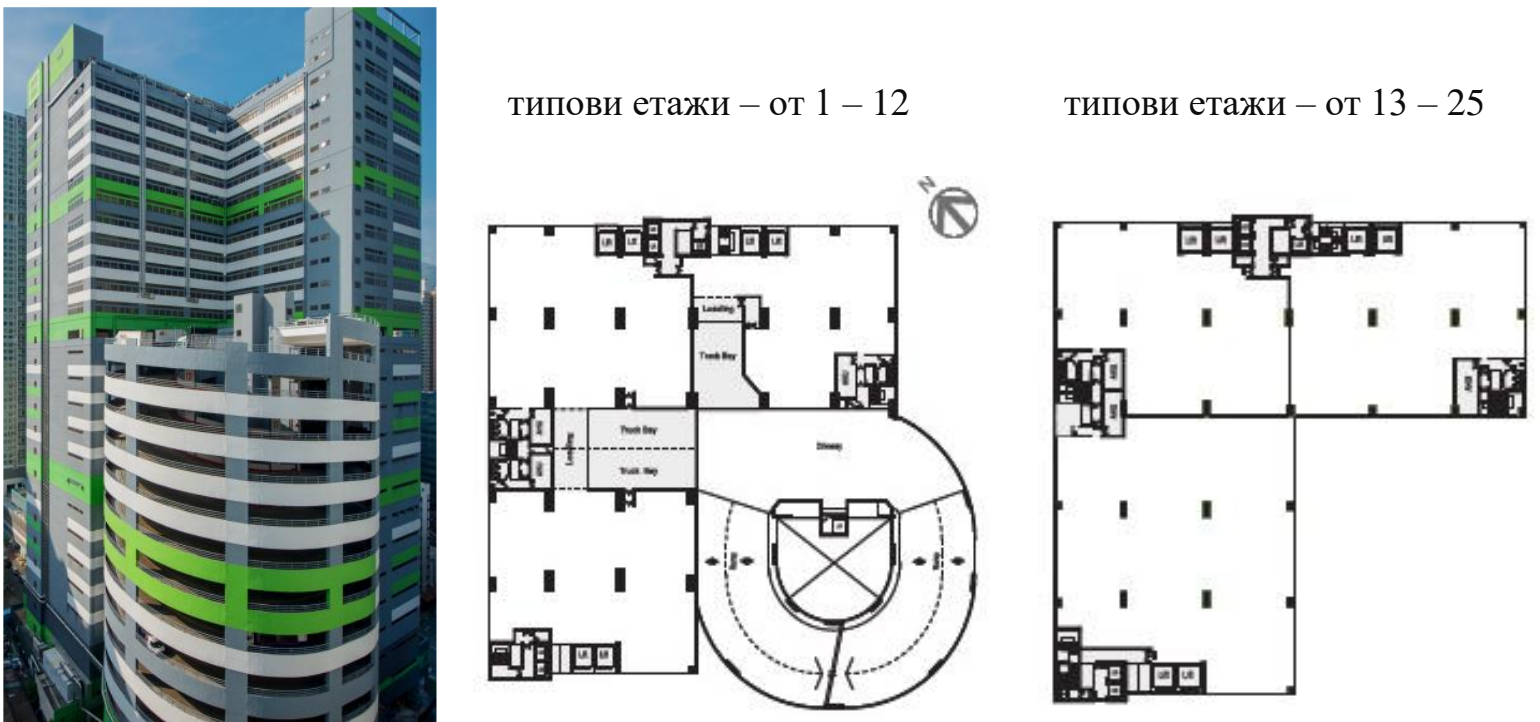

Pис 5. - GOODMAN GLOBAL GATEWAY в Хонконг - изгледи и разпределения на типови етажи - от 1 - 12, обслужвани от автомобилен транспорт и от 13 - 25, обслужвани от 6 товарни асансьора с товароподемност 3,00т. Етажите са със светла височина 5,80 м. Полезният товар на междуетажната конструкиия е 1250 - 1500 к2/м
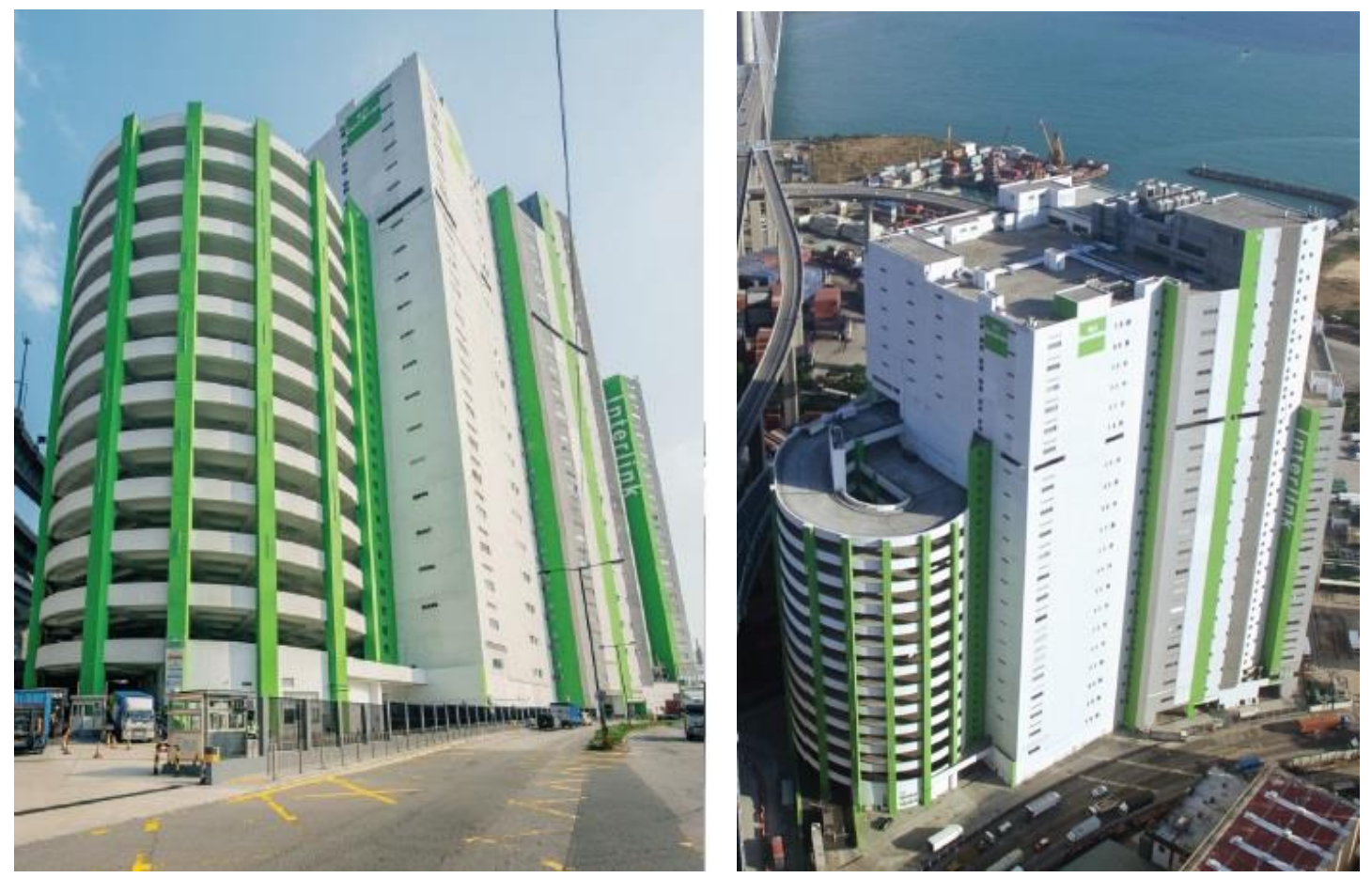

Puc. 6. - GOODMAN INTERLINK в Хонконг - изгледи 

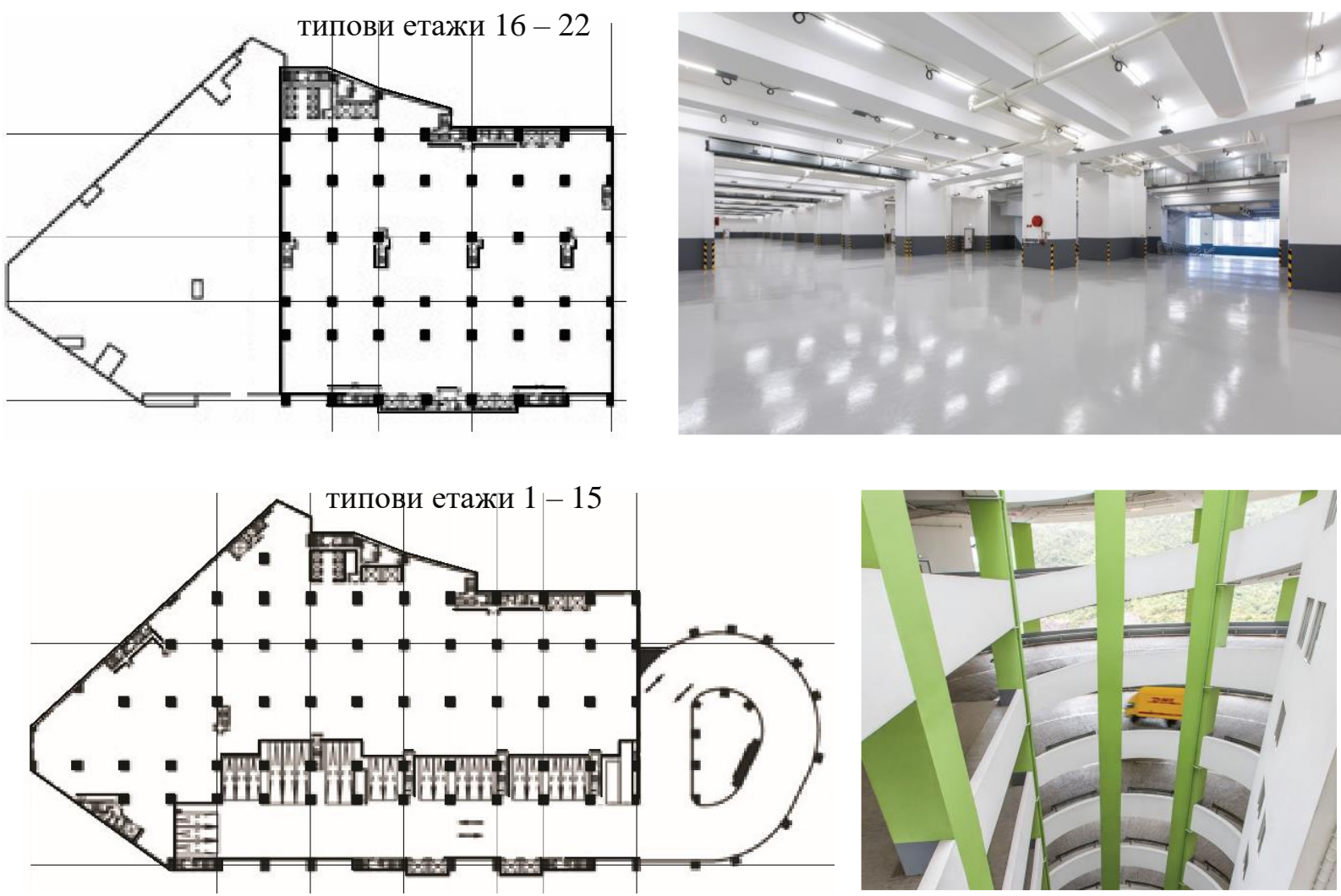

Puc. 7. - GOODMAN INTERLINK в Хонконг - разпределения на типови етажи 1 - 15, и 16 - 22, обслужвани от автомобилен транспорт и от товарни асансьори. Изгледи от комуникационна и товаро-разтоварна рампа.

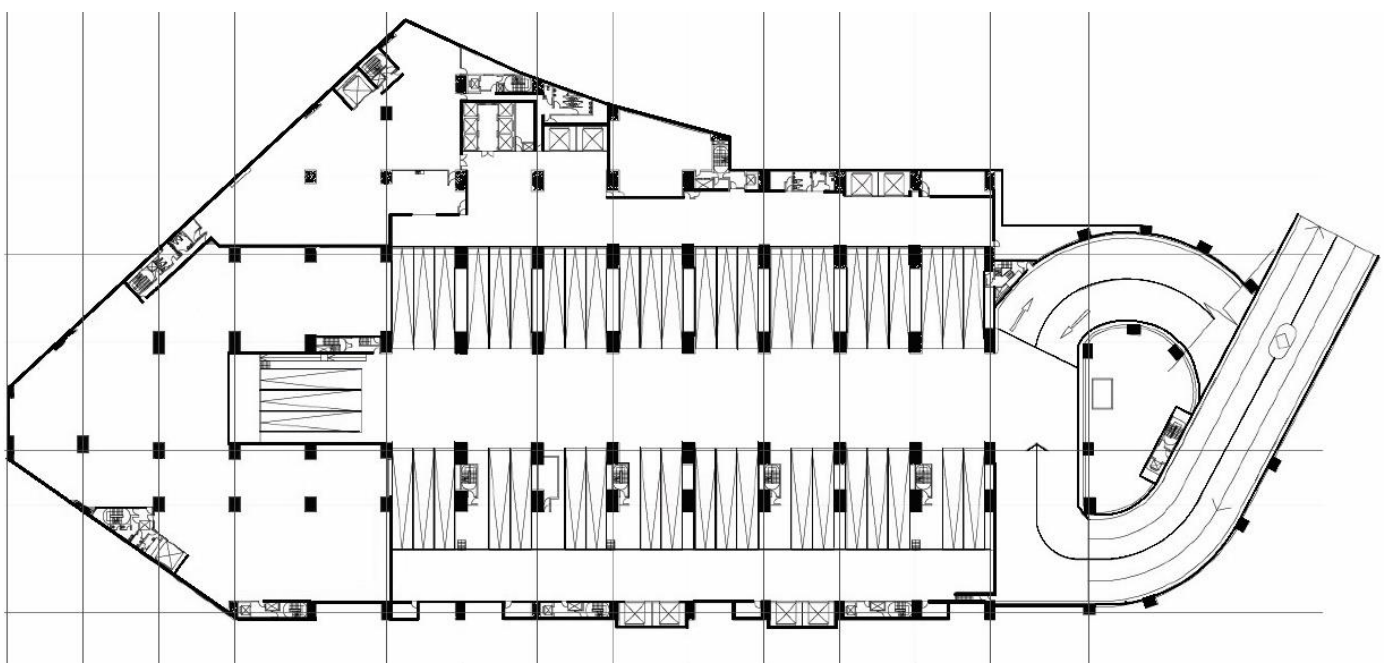

PUc. 8. - GOODMAN INTERLINK в Хонконг - разпределение на приземния етаж, на който се осъществява връзката между тежкия автомобилен транспорт и складовите площи над 15-тия етаж посредством 10 товарни асансьора с товароподемност 5,0 m. Осигурен е фронт на товаро-разтоварните рампи за 44 броя 18,00-метрови ТИР-а.

Високите сгради за логистика от третия тип /с криволинейни двупосочни рампи и групи товарни асансьори/ съчетават най-сьществените технологично-икономически предимства на едноетажните логистични сгради и на многоетажните складове с товарни асансьори - бързия товарооборот на високо ликвидните стоки и интензивното използване на скъпите градски терени в условията на все по-голямо по обем и по-разнообразно по асортимент потребление. От гледна 
точка на устойчивостта в развитието на градските територии, използването на високите сгради (120 - 150 м.) с подиум, който обхваща 90-100\% от имота е възможност за съхраняване на компактната структура на града (при условие, че тя съществува към момента) и намаляване на риска от неконтролируемо разпростиране на града.

Тези предимства предполагат бъдещото по-широко разпространение на типа „логистичен небостъргач с частичен автомобилен достъп“ не само в Хонконг но и в други градове с високи темпове на икономическо развитие, висок естествен прираст на населението, ограничен ресурс откъм терени за строителни цели и обществено осъзната необходимост от устойчиво развитие на урбанизираната структура.

\section{ЛИТЕРАТУРА}

1. https://www.eft.com/land-challenges-hong-kongs-logistics-sector

2. https://www.pland.gov.hk/pland_en/tech_doc/hkpsg/full/ch5/ch5_text.htm

3. http://global.ctbuh.org/resources/papers/download/2625-deep-foundations-for-high-rise-buildings-in-hongkong.pdf

4. http://www.hko.gov.hk/gts/equake/sig_eq_chance_e.htm

5. https://www.goodman.com

6. *CBRE Group, Inc. е най-голямата фирма за услуги и инвестиции в областта на недвижимите имоти в света, с приходи от \$10,9 милиарда /2015/ и повече от 70,000 служители.

7. https://www.cbre.com/research-and-reports/apac-multi-storey-warehouses-2016 